\title{
Immunohistochemistry of norepinephrine transporters in the vagus nerve in a rat model of epilepsy
}

\section{Sıçanlarda epilepsi modelinde vagus sinirinde norepinefrin tașıyıcılarının immünohistokimyası}

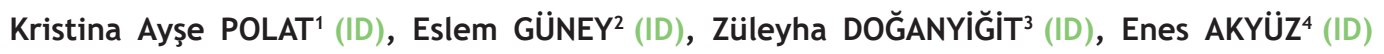

\section{ABSTRACT}

Objective: Epileptic seizures occur as a result of the excessive and uncontrolled spread of electrical activity. Studies have reported that epileptic seizures may affect the autonomic function. However, the main molecular mechanism has not been elucidated yet. Since the vagus nerve (VN) carries $75 \%$ of all parasympathetic autonomic system fibers, it is of great importance in the autonomic center associated with epilepsy pathogenesis. Afferent sensory fibers of the VN have connections to associated regions in the brainstem, providing norepinephrine (NE) transmission. Therefore, the suppressive effect of NE on seizures and the role of NE transporters (NET) in neurotransmitter reuptake may occur. Examining the neurotransmitters and related transporters in the autonomic nervous system at the molecular level may help to understand the related mechanism. In this study, we aimed to determine the NET-associated immunoreactivity in the VN in pentylenetetrazole (PTZ) epilepsy model.

Methods: Epileptic seizures were induced in Wistar rats $(280-380 \mathrm{~g})$ by administering PTZ [first 12 injections $35 \mathrm{mg} / \mathrm{kg}$, intraperitoneal (I.P.) and last injection $50 \mathrm{mg} / \mathrm{kg}$ I.P.] for 28 days. Subsequently, the VN was

\section{ÖZET}

Amaç: Epileptik nöbetler elektriksel aktivitenin aşırı ve kontrolsüz șekilde yayılmasının bir sonucu olarak ortaya çıkmaktadır. Yapılan çalıșmalar epileptik nöbetlerin otonomik işlevi etkileyebileceğini bildirmiștir. Ancak moleküler mekanizma henüz tam olarak aydınlatılamamıștır. Vagus siniri (VS) tüm parasempatik sistem liflerinin \%75'ini tașıdığından dolayı epilepsi patogeneziyle ilișkili otonomik merkezde büyük bir öneme sahiptir. Afferent duyusal lifleri beyin sapındaki ilișkili bölgelerdeki bağlantılar aracılığıyla sinapslar arası norepinefrin (NE) iletimini sağlamaktadır. Böylece, NE'nin nöbetler üzerinde baskılayıcı etkisi ve NE taşıyıcılarının (NET) nörotransmitter geri alımındaki görevi olușabilir. Otonom sinir sisteminde görev alan nörotransmiterler ve ilgili tașıyıcıların moleküler düzeyde incelenmesi ilișkili mekanizmanın anlașılmasına yardımcı olabilir. Bu çalıșmada pentilentetrazol (PTZ) epilepsi modelinde NET ile ilișkili immünoreaktivitenin belirlenmesi amaçlanmıștır.

Yöntem: Epileptik nöbetler Wistar sıçanlarında (280-380g) 28 gün boyunca PTZ [ilk 12 enjeksiyon 35 mg/ $\mathrm{kg}$, intraperitoneal (I.P.) ve son enjeksiyon $50 \mathrm{mg} / \mathrm{kg}$ I.P.] uygulanarak indüklendi. Daha sonra VS torakal ve servikal

'Yozgat Bozok University, Faculty of Medicine, Yozgat

${ }^{2}$ Zonguldak Bulent Ecevit University, Faculty of Medicine, Zonguldak

${ }^{3}$ Yozgat Bozok University, Faculty of Medicine, Department of Histology, Yozgat

${ }^{4}$ Yozgat Bozok University, Faculty of Medicine, Department of Biophysics, Yozgat

İletişim / Corresponding Author : Enes AKYÜZ

Yozgat Bozok Üniversitesi, Tıp Fakültesi, Biyofizik Anabilim Dalı, Yozgat - Türkiye

E-posta / E-mail : enesakyuz25@gmail.com

Geliş Tarihi/Received : 27.11.2020

Kabul Tarihi/Accepted : 20.12.2020

DOI ID : 10.5505/TurkHijyen.2020.74507

Polat KA, Güney E, Doğanyiğit Z, Akyüz E. Immunohistochemistry of norepinephrine transporters in the vagus nerve in a rat model of epilepsy. Turk Hij Den Biyol Derg, 2021; 78(2): 167 - 174 
dissected as two parts, in terms of the thoracic and cervical sections. The NET levels were evaluated by immunohistochemical staining on the tissue samples.

Results: Expression of NETs in the thoracic VN region of the male and female experimental groups significantly increased. In the cervical VN, NET expression was significantly increased in epileptic male rats, while decreased in epileptic female rats compare to control groups.

Conclusion: Our study may disclose significant regional enhancement in the NET immunoreactivity. It is assumed that NET, which plays a role in NE regulation, may be characterized by abnormal neural stimulation. The findings provide proof-of-concept that alterations in NET expression may affect the ANS dysfunctions associated with epilepsy.

Key Words: Epilepsy, PTZ, autonomic nervous system, norepinephrine kesitler açısından iki parça halinde diseke edildi. NET seviyeleri doku örnekleri üzerinde immünohistokimyasal boyama ile değerlendirildi.

Bulgular: Erkek ve diși deney gruplarının torakal vagus bölgesinde NET ifadesinin anlamlı olarak arttı. Servikal VS'de NET ekspresyonu epileptik erkek sıçanlarda önemli ölçüde artarken, epileptik diși sıçanlarda kontrol gruplarına göre azaldı.

Sonuç: Çalıșmamız VS'de NET ifadesinin anlamlı bölgesel artıșlarını ortaya koymuștur. NE regülasyonunda rol alan NET'in parasempatik sinirsel uyarım bozukluğu ile karakterize olabildiği düşünülmektedir. Gözlemlenen NET ifadesindeki değișiklikler epilepsi ile ilișkili otonom sinir sistemi ișlev bozukluklarını etkileyebileceğine dair kanitlar sunabilir.

Anahtar Kelimeler: Epilepsi, PTZ, otonom sinir sistemi, norepinefrin

\section{INTRODUCTION}

Epilepsy is a neurological symptom complex. This disease includes multiple risk factors and genetic predisposition. Seizures may occur in more than 70 million people $(1,2)$. Epileptic seizures generally can affect autonomic functions. Therefore, triggers in central and autonomic networks may contribute to pathologies in the cardiovascular system. Chronic and repeated activation of the autonomic nervous system (ANS) in patients with epilepsy can trigger fatal arrhythmias (3-5). To eludicate of the ANS related molecular mechanism is of great importance to clarify epilepsy pathogenesis.

Sympathetic, parasympathetic, and enteric systems, maintain nervous control of all body parts except skeletal muscle (6). The vagus nerve (VN) provides a large part of the ANS-mediated nerve conduction (7-9). VN and brainstem are considered autonomic targets in terms of sympathetic/ parasympathetic effects in seizure suppression (10).

After triggering, $\mathrm{VN}$ fibers may accelerate the neural activity in the locus coeruleus (LC), which is the regulatory center of the noradrenergic system in the brainstem (11). The noradrenergic pathway is one of the main neuro-modulatory systems that play an essential role in attention, arousal, and cognition $(12,13)$. The LC releases the neurotransmitter norepinephrine (NE) in various anatomically and functionally diverse brain regions (13). Depending on the seizure type or the area of the brain affected, reduced NE expressions and decreased adrenergic receptor density is reported. Therefore, it has been observed that pharmacological agents that increase extracellular NE levels have anticonvulsant effects (14). 
The NE transporter (NET) is responsible for the reuptake of sodium chloride $(\mathrm{Na}+/ \mathrm{Cl}-)$ bound extracellular NE into the presynaptic neurons. NET also provides a reuptake of extracellular dopamine (DA) $(15,16)$. The uptake of these two neurotransmitters into the presynaptic neuron is of great importance in regulating the concentrations in the synaptic cleft.

In this study, we aimed to determine the NETassociated immunoreactivity in the $\mathrm{VN}$ of the experimental epilepsy model.

\section{MATERIAL and METHOD}

A total of 28 adult male and female Wistar albino rats weighing between $280-400 \mathrm{~g}$ were randomly divided into 4 groups. The rats were placed in cages at controlled temperatures $\left(24^{\circ} \mathrm{C} \pm 2{ }^{\circ} \mathrm{C}\right)$ and kept on a 12-hour light-dark cycle. Free access to water and standard food was provided to animals. All efforts were made to minimize suffering by anesthetizing rats with ketamine/xylazine $[90 / 10 \mathrm{mg} / \mathrm{kg}$, intraperitoneal (I.P.), respectively]. The experimental protocol of this study was approved by Kayseri Erciyes University Animal Ethics Committee (ethics committee decision no: 2019/027). All procedures were followed under the recommendations in the National Institutes of Health (USA) and the Guidelines for the Care and Use of Laboratory Animals adopted by the Helsinki Declaration.

\section{PTZ-Kindling Model}

Female and male control groups $(\mathrm{n}=7)$ were injected equally and a total of $0.5 \mathrm{cc}$ intraperitoneal (I. P.) saline was given every two days.

Seizures were induced in female and male experimental groups $(n=7)$ with periodic administration of PTZ (35 mg/kg, I. P.) for one month. PTZ (P6500, Sigma, St. Louis, MO, USA), a GABAA receptor antagonist used in the model, was dissolved in $0.9 \% \mathrm{NaCl}$ solution and adjusted to $35 \mathrm{mg} / \mathrm{kg}$ dose. The solution was injected into rats three days a week for a month for a total of 12 doses, and seizure behavior was observed 30 minutes after injection and calculated according to the Racine scoring protocol.

One week after the last PTZ injection, animals were given high dose PTZ (50 mg/ $\mathrm{kg}$, I.P.) to demonstrate improved seizure sensitivity in both female and male PTZ groups. Phase 4 or 5 was expected to be seen to observe the ignition pattern (17).

\section{Racine Scoring System}

Racine scoring (RS) was used to assess seizure severity in rodent experimental epilepsy models (18). RS, which categorizes the stages of seizures,

Stage 0: No answer,

Stage 1: Twitching in the ear and face,

Stage 2: Myoclonic jerks in the body,

Stage 3: Standing up on hind legs,

Stage 4: Tonic-clonic seizures with the animal falling to the ground,

Stage 5: Recurrent (generalized) severe tonicclonic seizures.

3. Immunohistochemical Analysis

NET immunoreactivity was detected in thoracic and cervical nerve samples of the experimental groups using the Avidin-Biotin peroxidase method (Figure 1).

After the deparaffinization of the sections taken at $5 \mu \mathrm{m}$ thickness, citrate buffer was used to open the epitopes ( $\mathrm{pH}: 6.0)$. Subsequently, $3 \%$ hydrogen peroxide in methanol was taken into the solution to prevent endogenous peroxidase activity. Apply Ultra $\mathrm{V}$ block solution to prevent unspecific staining. Sections were incubated overnight at $40{ }^{\circ} \mathrm{C}$ with Anti-NET Antibody (Alomone lab: AMT-002). The sections were counterstained with Gill Hematoxylin by applying biotinylated secondary streptavidin-HRP (TP-125-HL; Thermo Scientific) and DAB chromogens, respectively. It was dehydrated through increasing alcohol series and closed with a sealer called entellan. Sections were examined with an Olympus BX53 light microscope. The evaluation of immunoreactivity levels was made with the Image J program. 


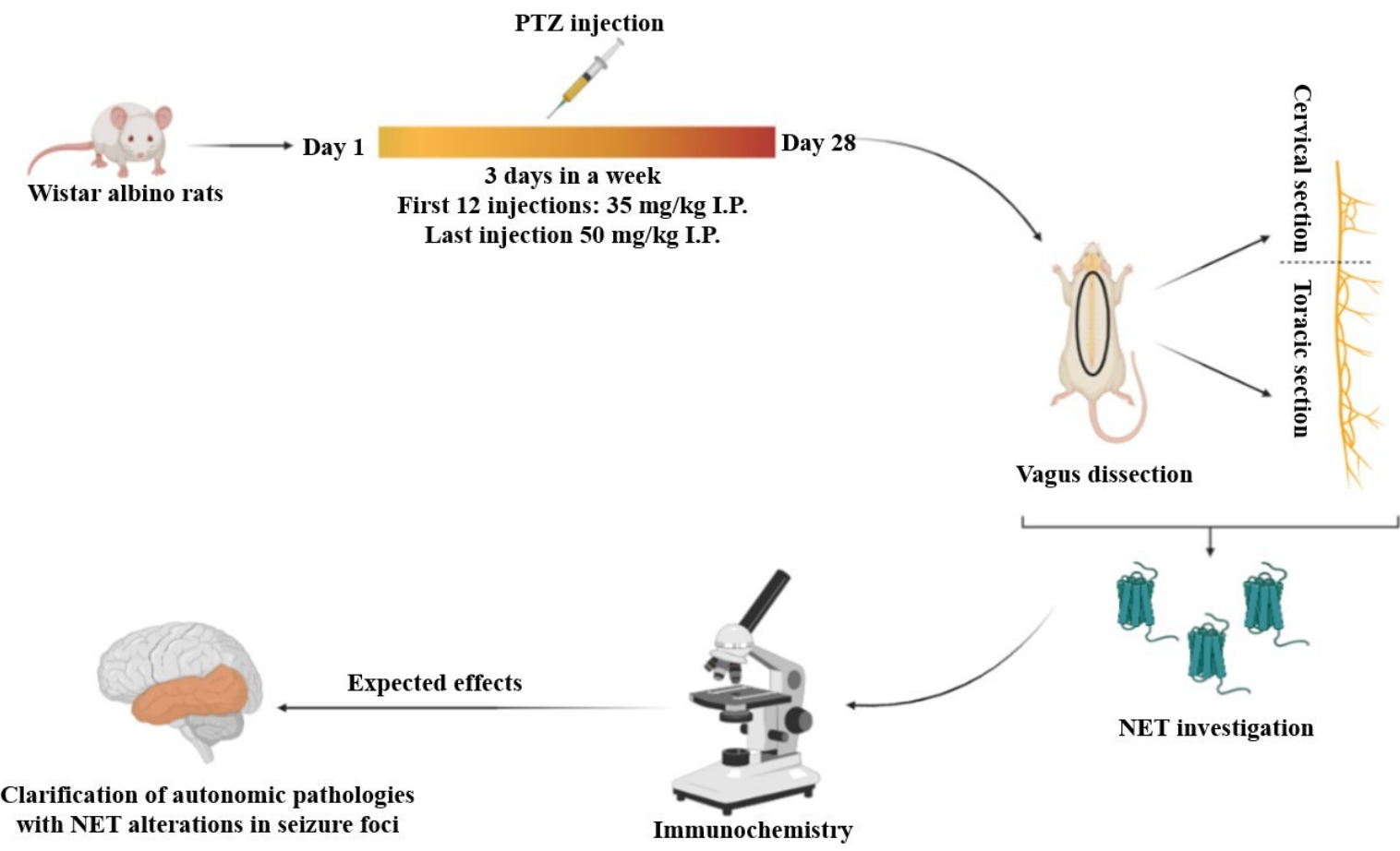

Figure 1. Diagram summarizing the methodology steps used in the study. After the PTZ induction model, vagus dissection was performed. NET changes were observed with immunohistochemical examinations.

PTZ, Pentylenetetrazole; NET, Norepinephrine transporter

\section{Statistical analysis}

Considering the norepinephrine variable, power analysis results with alpha $=0.05$, power $=80 \%$. Accordingly, it was calculated that there should be at least 7 subjects in each group. In addition, the data obtained were statistically compared with each other in the SPSS statistical package program.

\section{RESULTS}

\section{Scores of PTZ Kindling Epilepsy Model}

After the PTZ kindling, epileptic seizures were gradually induced. Generalized tonic-clonic seizures, corresponding to phase 5 of the Racine's scaling system score, were observed in both male and female rats at the 13th injection. Latency to first seizure was calculated for both groups. PTZ-kindled female rats had their first seizure in $266 \pm 66 \mathrm{~s}$, while PTZ-kindled male rats had their first seizure in $308 \pm 95 \mathrm{~s}$. No significant changes were observed in the body weights of the rats during the PTZ injection procedure.

\section{Immunohistochemical Findings}

NET significantly increased in both male and female experimental groups in thoracic VN tissue $(p<0.05)$. In the cervical $V N$ region, NET expression decreased in the experimental groups in female rats, while it increased in the experimental groups in male rats $(\mathrm{p}<0.05)$ (Figure 2$)$.

\section{DISCUSSION}

In this paper, the role of autonomic $\mathrm{VN}$ involvement in epilepsy was investigated in terms of the NET, which plays a key role in central nervous system. In the thoracic VN of epileptic rats, a significant increase in NET immunoreactivity was observed. On 
A

Thoracic nerve

\section{Cervical nerve}

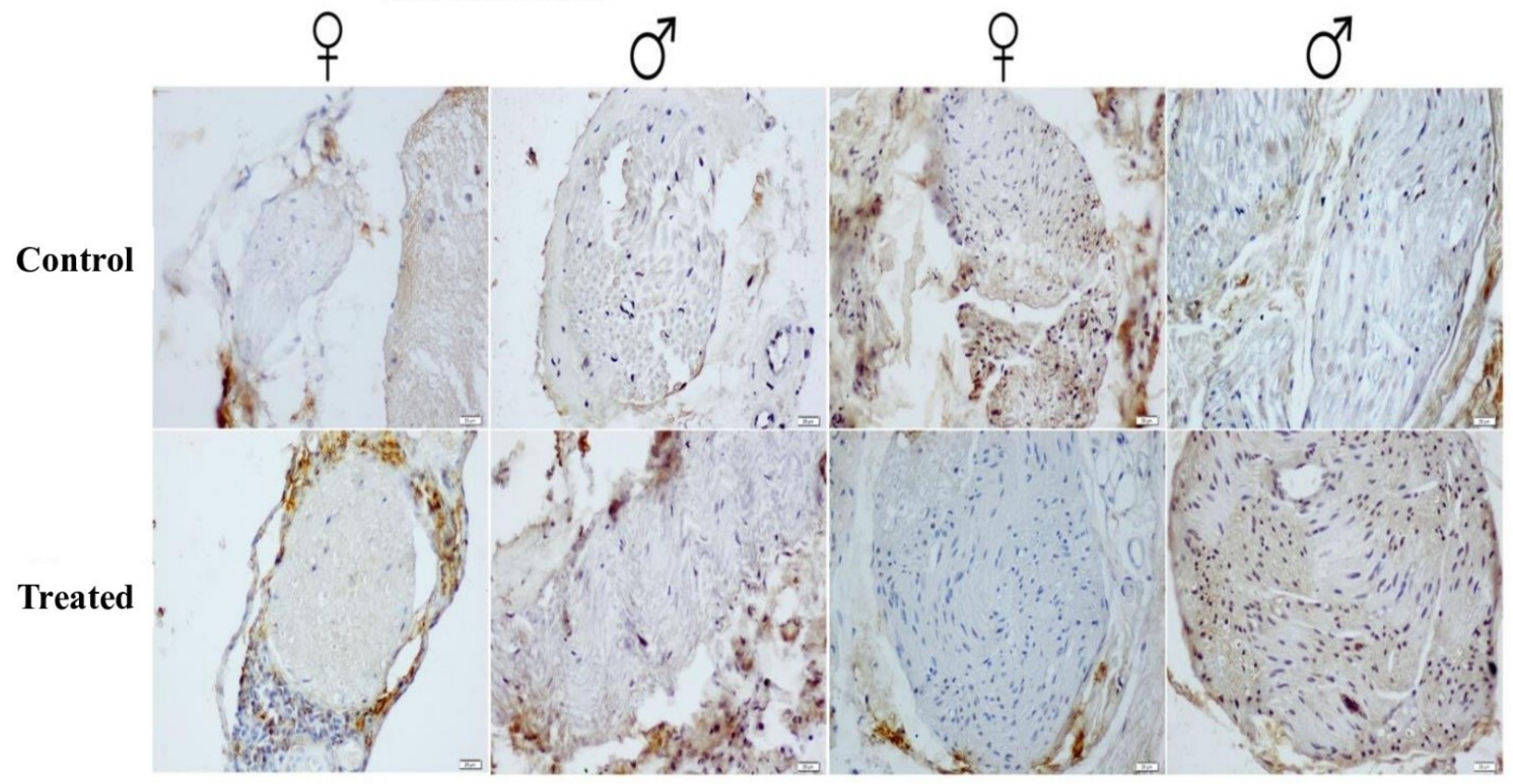

B

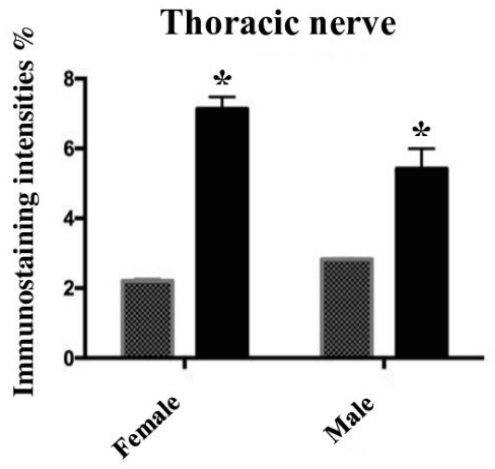

Norepinephrine transporter
Cervical nerve

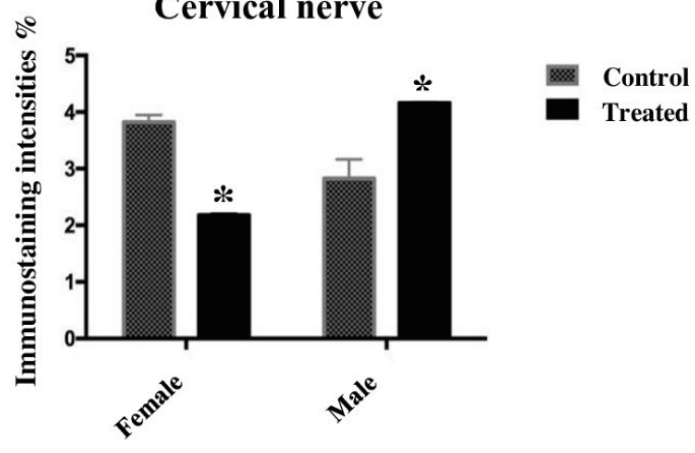

Norepinephrine transporter

Figure 2. Immunoreactivity results of NET in the VN. In both groups, increased immunoreactivity in thoracic VN was observed. Pictures were taken at a magnification of $\times 40$. Scale bar: $20 \mu \mathrm{m}$

(A). The histogram graph showing the fold change in immunoreactivity for NET in the VN. The data are expressed as the mean \pm SEM.

(B). One-way ANOVA variance analysis and Sidak's multiple comparison test were applied.

${ }^{*} p<0.05$. NET, Norepinephrine transporter; SEM, Standard error; ANOVA, Analysis of variance

the other hand, NET expression was reduced in the cervical VN in male PTZ rats, while it increased in female PTZ rats. We hypothesized that NET, which is characterized by regional increases in the $\mathrm{VN}$, may trigger the reuptake of synaptic NE to the presynaptic region, producing excitation that occurs in epilepsy.
Several studies conducted that endogenous NE has an anticonvulsant role in epilepsy. Additionally, NE reduction has been characterized by increased neuron damage in limbic regions and susceptibility to epileptic seizures $(19,20)$. 
Convulsive activity is partially regulated by inhibiting neuronal processes, and catecholamines, DA, and NE act as central seizure suppressors. Although current evidence provides implications for the antiepileptic role of DA at the receptor level, NE has been revealed as the primary seizure suppressor (21). Recent studies revealed that NE plays an important role in modulation seizures by diminishing stimulation of limbic areas such as the amygdala and hippocampus $(22,23)$. Considering NE innervation, the anterior piriform cortex was examined in rats to examine susceptibility to seizures. Damage to the LC terminals was accomplished by the selective neurotoxin bromobenzyl amine (60 mg/ $\mathrm{kg}$ I.P.). In intact rats, a marked increase in NE release in the contralateral piriform cortex was accompanied by sporadic seizures. The observations disclosed that epileptic rats developed neuronal loss in various limbic regions (24). The fact that NE shows a decrease in epilepsy due to damage to the brain regions suggests that it may lead to neuroinflammation.

In vitro studies have shown that excitotoxicity occurs in neurons as a result of electrical VN stimulation (VNS) for 12-14 hours $(25,26)$. Besides, VNS is known to be a method used in epilepsy and preventing autonomic system disorders (27). VNS activates the parasympathetic components of the VN to achieve therapeutic effects. However, in addition to the parasympathetic nerves, the cervical and thoracic $\mathrm{VN}$ regions contain components that form sympathetic nerve fibers $(28,29)$. Due to the connection between stellate ganglion (SG) and VN, stimulation of the sympathetic component with NE may activate the ganglion cells in SG at high rates. Current data have shown that VNS may have antiadrenergic effects in acute studies and suppress SG nerve activity during chronic trials (30).

In our study, the increase of NE-related receptors in the thoracic $\mathrm{VN}$ region and a decrease in the cervical $\mathrm{VN}$ in male rats showed that noradrenergic reuptake mechanisms in sympathetic and parasympathetic fibers might be increased in epilepsy. Additionally, we assume that NE reuptake may cause neuronal damage by mediating excitotoxicity in sympathetic ganglia.

$\mathrm{NE}$, acetylcholine $(\mathrm{ACh})$, and serotonin provide astrocyte-mediated extracellular $\mathrm{K}+$ regulation. It has been reported that NE and serotonin-mediated $\mathrm{K}+$ flow reduces as a result of Kir4. 1 channel blockade (31). Considering all data, we estimate that NE may prevent abnormal depolarization by providing $\mathrm{K}+$ flow into the cell.

The effects of the VN in the autonomic system can vary depending on gender as a result of the difference in receptors and ion channels. A study examining $\mathrm{ACh}$ receptors on the vagus nerve in epilepsy, revealed that the increase in ACh was greater in female rats (32). Studies examining the effect of sympathetic activity on blood pressure through catecholamines disclosed that NE-related voltage-dependent $\mathrm{K}+(\mathrm{KV})$ channels are expressed at various rates between genders depending on hormonal and developmental effects. Accordingly, catecholamine release due to increased channel activity in female rats was significantly reduced (33). Furthermore, Kir channel expressions and cardiac morphology have been reported to vary depending on gender $(34,35)$. In our study, NET expression was decreased in females and decreased in male experimental rats in the cervical VN. The results demonstrated that NE may affect pathologies, such as neuronal damage concerning the number of sex-based receptors. However, gender-based change in ion channels and receptor interactions of neurotransmitters has not been fully elucidated.

This study provided evidence that NET change in the VN, which acts as a "bridge" between the brain and heart, may be associated with autonomic dysfunction accompanying epilepsy.

In conclusion, despite extensive development in pre-clinical and clinical research, the precise mechanism of the noradrenergic system in $\mathrm{VN}$ origin for epilepsy is not fully known. In this study, we 
hypothesized that NET increase in the thoracic VN and decrease in the cervical VN in male rats may occur as a result of the imbalance of NE reuptake mechanisms in sympathetic-parasympathetic fiber connections as a result of epileptic discharges. Thus, new treatment methods should be investigated, especially for drugresistant cases, by enlightening the entire molecular mechanism centered on the VN.

\section{ACKNOWLEDGMENTS}

The data used in this study were financially supported by The Scientific and Technological Research Council of Turkey (TUBITAK) the 2209-A University Students Research Projects Support Program with the project number 1919 B011902031.

\section{ETHICS COMITTEE APPROVAL}

* The study was approved by the Kayseri Erciyes University Animal Ethics Committee (Date: : 13.02.2019 and Number: 2019/027).

\section{CONFLICT OF INTEREST}

The authors declare no conflict of interest.

\section{REFERENCES}

1. Fisher RS, Acevedo C, Arzimanoglou A, Bogacz A, Cross JH, Elger CE et al. ILAE official report: a practical clinical definition of epilepsy. Epilepsia, 2014;55: 475-82.

2. Thijs RD, Surges R, O’Brien TJ, Sander JW. Epilepsy in adults. Lancet, 2019;393: 689-701.

3. Devinsky O, Ryvlin P, Friedman D. Preventing Sudden Unexpected Death in Epilepsy. JAMA Neurol, 2018;75: 531-2.

4. Goldenholz DM, Kuhn A, Austermuehle A, Bachler M, Mayer C, Wassertheurer $S$ et al. Long-term monitoring of cardiorespiratory patterns in drugresistant epilepsy. Epilepsia, 2017;58: 77-84.

5. Van der Lende M, Surges R, Sander JW, Thijs RD. Cardiac arrhythmias during or after epileptic seizures. J Neurol Neurosurg Psychiatry, 2016;87: 69-74.

6. Wehrwein EA, Orer HS, Barman SM. Overview of the Anatomy, Physiology, and Pharmacology of the Autonomic Nervous System. Compr Physiol, 2016;6: 1239-78.

7. Tindle J, Tadi P. Neuroanatomy, Parasympathetic Nervous System. StatPearls, StatPearls Publishing LLC, 2020.

8. English BA, Jones CK. Chapter 14 - Cholinergic Neurotransmission. Primer on the Autonomic Nervous System (Third Edition). San Diego: Academic Press, 2012.
9. Thompson N, Mastitskaya S, Holder D. Avoiding off-target effects in electrical stimulation of the cervical vagus nerve: Neuroanatomical tracing techniques to study fascicular anatomy of the vagus nerve. J Neurosci Methods, 2019;325: 108325.

10. Barot N, Nei M. Autonomic aspects of sudden unexpected death in epilepsy (SUDEP). Clin Auton Res, 2019;29: 151-60.

11. Hulsey DR, Shedd CM, Sarker SF, Kilgard MP, Hays SA. Norepinephrine and serotonin are required for vagus nerve stimulation directed cortical plasticity. Exp Neurol, 2019;320: 112975.

12. Bouret S. Locus Coeruleus, Noradrenaline, and Behavior: Network Effect, Network Effects? Neuron, 2019;103: 554-6.

13. Schwarz LA, Luo L. Organization of the locus coeruleus-norepinephrine system. Curr Biol, 2015;25: R1051-r1056.

14. Kumar U, Medel-Matus JS, Redwine HM, Shin D, Hensler JG, Sankar R et al. Effects of selective serotonin and norepinephrine reuptake inhibitors on depressive- and impulsive-like behaviors and on monoamine transmission in experimental temporal lobe epilepsy. Epilepsia, 2016;57: 506-15.

15. Tellioglu T, Robertson D. Genetic or acquired deficits in the norepinephrine transporter: current understanding of clinical implications. Expert Rev Mol Med, 2001;2001: 1-10. 
16. Wayment HK, Schenk JO, Sorg BA. Characterization of extracellular dopamine clearance in the medial prefrontal cortex: role of monoamine uptake and monoamine oxidase inhibition. J Neurosci, 2001;21: 35-44.

17. Löscher W. Animal Models of Seizures and Epilepsy: Past, Present, and Future Role for the Discovery of Antiseizure Drugs. Neurochem Res, 2017;42: 187388.

18. Racine RJ. Modification of seizure activity by electrical stimulation: II. Motor seizure. Electroencephalogr Clin Neurophysiol, 1972;32: 281-94.

19. Midzyanovskaya I, Shatskova A, MacDonald E, Van Luijtelaar G, Tuomisto L. Brain aminergic deficiency in absence epileptic rats: Dependency on seizure severity and their functional coupling at rest. J Behav Brain Sci, 2020;10: 29-45.

20. Stevens L, Vonck K, Van Lysebettens W, Baekelandt V, Van Den Haute C, Carrette E et al. Genetic modification of Locus Coeruleus NE cells for chemogenetic activation remains challenging. Front Neurosci Conference, 2019.

21. Hui Yin Y, Ahmad N, Makmor-Bakry M. Pathogenesis of epilepsy: challenges in animal models. Iran J Basic Med Sci, 2013;16: 1119-32.

22. Deal AL, Mikhailova MA, Grinevich VP, Weiner JL, Gainetdinov RR, Budygin EA. In vivo voltammetric evidence that locus coeruleus activation predominantly releases norepinephrine in the infralimbic cortex: Effect of acute ethanol. Synapse, 2019;73: e22080.

23. Stevens L, Vonck K, Larsen LE, Van Lysebettens W, Germonpré C, Baekelandt V et al. A Feasibility Study to Investigate Chemogenetic Modulation of the Locus Coeruleus by Means of Single Unit Activity. Front Neurosci, 2020;14: 162

24. Giorgi FS, Ferrucci M, Lazzeri G, Pizzanelli C, Lenzi $\mathrm{P}$, Alessandrl MG et al. A damage to locus coeruleus neurons converts sporadic seizures into selfsustaining limbic status epilepticus. Eur J Neurosci, 2003;17: 2593-601.

25. Jaiswal MK, Zech WD, Goos M, Leutbecher C, Ferri A, Zippelius A et al. Impairment of mitochondrial calcium handling in a mtSOD1 cell culture model of motoneuron disease. BMC Neurosci, 2009;10: 64.
26. Chinda K, Tsai WC, Chan YH, Lin AY, Patel J, Zhao $Y$ et al. Intermittent left cervical vagal nerve stimulation damages the stellate ganglia and reduces the ventricular rate during sustained atrial fibrillation in ambulatory dogs. Heart Rhythm, 2016;13: 771-80.

27. Planitzer U, Hammer N, Bechmann I, Glätzner J, Löffler S, Möbius R et al. Positional Relations of the Cervical Vagus Nerve Revisited. Neuromodulation, 2017;20: 361-8.

28. Onkka P, Maskoun W, Rhee KS, Hellyer J, Patel J, Tan J et al. Sympathetic nerve fibers and ganglia in canine cervical vagus nerves: localization and quantitation. Heart Rhythm, 2013;10: 585-91.

29. Seki A, Green HR, Lee TD, Hong L, Tan J, Vinters HV et al. Sympathetic nerve fibers in human cervical and thoracic vagus nerves. Heart Rhythm, 2014;11: 1411-7.

30. Rhee KS, Hsueh CH, Hellyer JA, Park HW, Lee YS, Garlie J et al. Cervical vagal nerve stimulation activates the stellate ganglion in ambulatory dogs. Korean Circ J, 2015;45: 149-57.

31. Wotton CA, Cross CD, Bekar LK. Serotonin, norepinephrine, and acetylcholine differentially affect astrocytic potassium clearance to modulate somatosensory signaling in male mice. J Neurosci Res, 2020;98: 964-77.

32. Akyüz E, Doğanyiğit Z, Paudel YN, Kaymak E, Yilmaz S, Uner A et al. Increased ACh-Associated Immunoreactivity in Autonomic Centers in PTZ Kindling Model of Epilepsy. Biomedicines, 2020;8.

33. Berg T. Kv7(KCNQ)-K(+)-Channels Influence Total Peripheral Resistance in Female but Not Male Rats, and Hamper Catecholamine Release in Hypertensive Rats of Both Sexes. Front Physiol, 2018;9: 117.

34. Akyüz E, Mega Tiber P, Beker M, Akbaș F. Expression of cardiac inwardly rectifying potassium channels in pentylenetetrazole kindling model of epilepsy in rats. Cell Mol Biol, (Noisy-le-grand) 2018;64: 47-54.

35. Akyuz E, Polat K, Ates S, Unalmis D, Tokpinar A, Yilmaz $S$ et al. Investigating Cardiac Morphological Alterations in a Pentylenetetrazol-Kindling Model of Epilepsy. Diagnostics, 2020;10: 388. 